\title{
Plasmids Formed in Nitrogen-fixing Escherichia coli-Klebsiella pneumoniae Hybrids
}

\author{
By F. C. CANNON, R. A. DIXON AND J. R. POSTGATE \\ A.R.C. Unit of Nitrogen Fixation, University of Sussex, Brighton, BNI $9 Q J$ \\ AND S. B. PRIMROSE \\ Department of Biological Sciences, University of Warwick, Coventry, CV $47 A L$
}

(Received 27 June 1973; revised 6 August 1973)

\section{SUMMAR Y}

Segments of the Klebsiella pneumoniae chromosome, which included the nitrogen fixation (nif) genes, were maintained as covalently closed circular molecules of DNA in Escherichia coli hybrids, C-M9 and C-L4. The R factor, RI44drd3, which had been used to confer fertility on the donor, was also detected as covalently closed circular DNA of molecular weight $(65 \pm 4) \times 10^{6}$ daltons according to sedimentation studies and electron microscopy.

The nif genes in hybrid C-M9 were linked to his on a plasmid which had a molecular weight of $9.5 \times 10^{6}$ daltons. A third plasmid in this hybrid had a molecular weight of $118 \times 10^{6}$ daltons. The Nif plasmid in C-M9 was transferred efficiently to other Escherichia coli strains only when R IdrdI9 was present in the donor in addition to RI44drd3.

Presence of three electrophoretically distinguishable gluconate-6-phosphate dehydrogenases was evidence for duplication of gnd determinants in C-M9. Resistance of both hybrids to the rough-specific phage $\phi \mathrm{X}$ I 74 suggested that they inherited Klebsiella his-linked $r f b$ genes.

Four plasmids were isolated from hybrid C-L4, one of which was Ri $44 d r d 3$. Two plasmids, one carrying his and nif and another met $\mathrm{G}$, were mobilized by RI 44drd3. The molecular weights of the C-L4 plasmids, excluding RI44drd3, were $(\mathrm{IO} 5 \pm \mathrm{I}) \times 10^{6}, 46 \times 10^{6}$ and $12 \times 10^{6}$ daltons.

\section{INTRODUCTION}

Genetic crosses between Escherichia coli $\mathrm{Hfr}$ strains and Salmonella typhosa recipients generate hybrids in which the inherited $E$. coli genes have not undergone recombination with the recipient chromosome (Baron, Gemski, Johnson \& Wohlhieter, I968). A comparable phenomenon has been observed in matings between E. coli and Shigella flexneri (Falkow, Schneider, Baron \& Formal, I963), between E. coli and Proteus mirabilis (Gemski, Wohlheiter \& Baron, 1967) and between E. coli and Salmonella typhimurium (Mojica-a \& Middleton, 1972). In the crosses between S. typhimurium and E. coli, exogenote hybrids in which the $E$. coli DNA did not integrate into the chromosome occurred at about the same frequency as haploid hybrids.

Analysis of their DNA revealed that the Escherichia coli genetic segments transferred were conserved in Salmonella typhosa as covalently closed circular (CCC) molecules (Leavitt et al. I97I). Though a 1ange of sizes was observed among the CCC molecules of the hybrids, each contained CCC molecules of a single characteristic size consistent with the presence in each of a different length of E. coli chromosome.

Intergeneric matings between Klebsiella pneumoniae and an Escherichia coli strain C 
recipient generating $\mathrm{His}^{+} \mathrm{Nif}^{+}$E. coli hybrids were reported by Dixon \& Postgate (1972). In a companion to this paper (Cannon, Dixon, Postgate \& Primrose, I974), we have presented data concerning a stable hybrid, strain C-M7, which led to the conclusion that the Klebsiella nif operon had probably become integrated into the $E$. coli chromosome as a segment of Klebsiella DNA carrying also his and the unselected markers gnd and $r f b$. Dixon \& Postgate (1972) reported the formation of three less stable hybrids which segregated Nif- segregants at high but variable frequencies. For one, strain C-M8, continued positive selection was necessary to conserve the hybrid state and it has now been lost. We now report a study of the two remaining hybrids, strains C-M9 and C-L4, including physico-chemical characterisation of their supercoiled DNA, their phage sensitivity and their inheritance of unselected markers, indicating that they conserve Klebsiella genetic material, including the nif operon, as CCCDNA molecules.

\section{METHODS}

Bacteria. Chatacteristics and sources of bacterial strains are given in Table I.

Bacteriophages. See Cannon et al. (1974).

Other procedures. Cannon et al. (1974) gave details of the procedures for culture, mating, acetylene tests for nitrogen fixation, isolation of clones resistant to phage $\mathrm{ECI}$, assay and electrophoresis of gluconate-6-phosphate dehydrogenase, and labelling, extraction, centrifugation and counting of DNA.

Electron microscopy. DNA was prepared for electron microscopy essentially as described by Davis, Simon \& Davidson (197I). A portion of $50 \mu \mathrm{l}$ of spreading solution, which contained Io $\mu \mathrm{l}$ of $0 . \mathrm{I} \%$ cytochrome $c, 50 \mu \mathrm{l}$ of I M-ammonium acetate and $40 \mu \mathrm{l}$ of dialysed material from ethidium bromide-CsCl gradients, was spread on a hypophase of $0.25 \mathrm{M}-\mathrm{NH}_{4}$ acetate. The film was picked up on grids coated with $3 \%$ parlodion, stained with uranyl acetate and air dried. Grids were rotary shadowed with Pt-Pd $(80: 20)$ and viewed in an AEI EM 6G electron microscope. Micrographs were taken at magnifications from 6000 to I6 000, using a $50 \mu \mathrm{m}$ objective aperture and $60 \mathrm{kV}$ accelerating voltage. Enlarged prints were traced on tracing paper and contour lengths of molecules measured with a map measurer. Molecular weights were estimated by measuring the contour length of colicin EI DNA prepared simultaneously with plasmids of hybrid C-L4, taking its molecular weight as $4.2 \times 10^{6}$ daltons and assuming proportionality to contour length.

\section{RESULTS}

\section{Mobilization of Klebsiella markers in Escherichia coli hybrids}

The presence of R $\mathrm{I} 44 d r d_{3}$ (the R factor used to promote transfer between Klebsiella pneumoniae and E. coli; Dixon \& Postgate, I972) in C-M9 and C-L4 was indicated by resistance to kanamycin, production of colicin $I$ and sensitivity to phage $\mathrm{If}_{2}$. The high transfer frequencies of kanamycin resistance to recipient strains (Table 2, Expts I and 4) showed that both hybrids possessed normal RI44drd3 sex factor activity.

The determinants his and met $\mathrm{G}$ were not transferred readily by RI $44 d_{r d}$ in hybrid C-M9 (Table 2, Expt I). In contrast, these markers were mobilized by this $\mathrm{R}$ factor in hybrid C-L4 at high frequency (Table 2, Expt 4) compared with control matings (Table 2, Expt 6) with $\mathrm{C} 603_{3}$ (R I 44drd3) as the donor ( $\mathrm{C} 603_{3}$ was the Escherichia coli recipient strain fiom which C-M9 and C-L4 were originally derived). In addition, his was transferred readily from C-L4 to SBI8OI (a KI 2 strain with a complete deletion of the his operon).

The F-like R factor R IdrdI9 was introduced into both hybrids from Escherichia coli $\mathrm{J}_{53}$; 

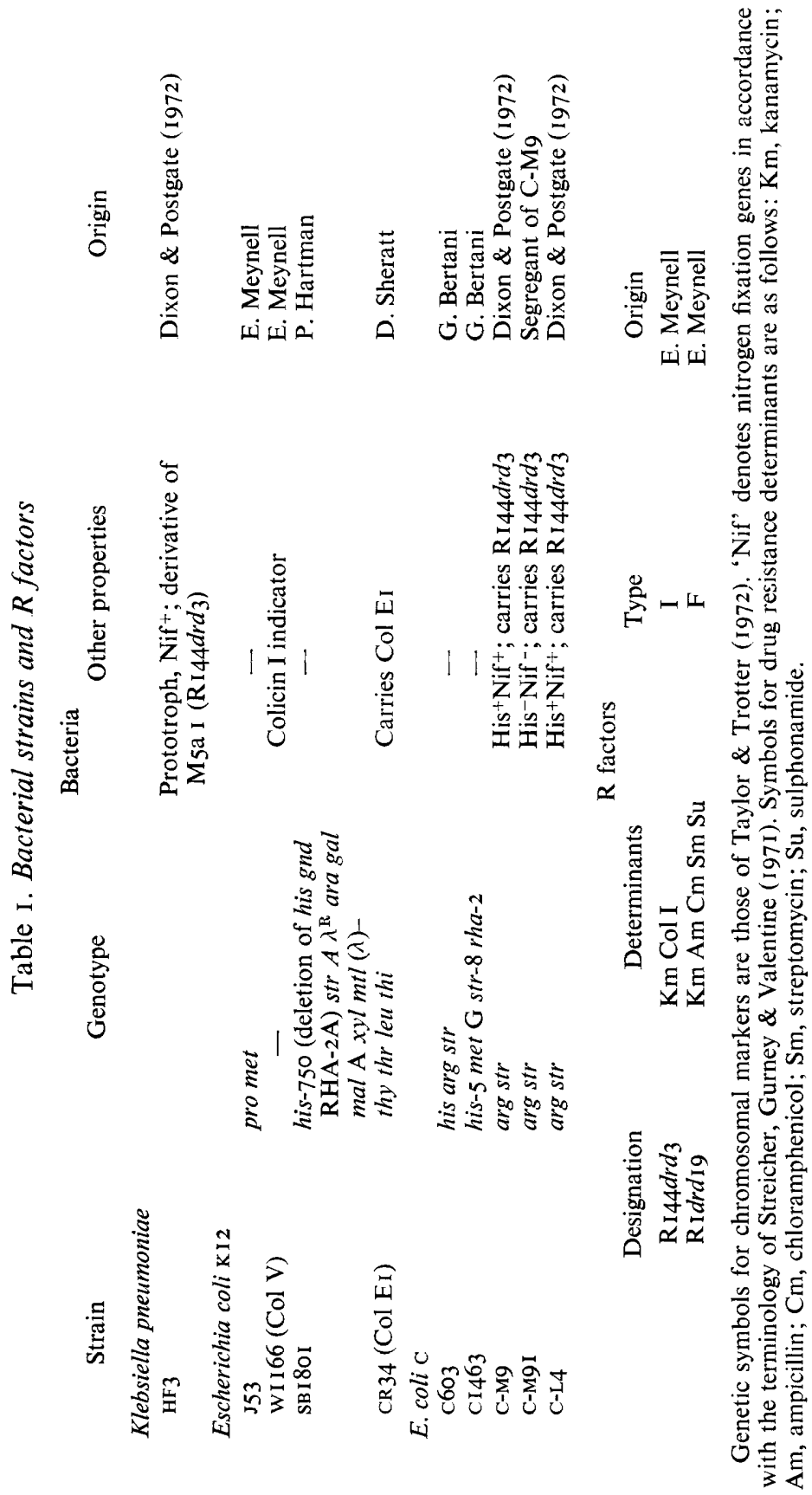
Table 2. Transfer characteristics of hybrids C-M9 and C-L4 carrying $\mathrm{RI} 44 d r d 3$ and RIdrdI9

Frequencies expressed/donor organism. $\mathrm{Km}$ denotes resistance to kanomycin, $\mathrm{Cm}$ resistance to chloramphenicol. In certain experiments exconjugants were purified by streaking on the selective medium and then tested for inheritance of unselected markers. No. of colonies inheriting unselected marker/total exconjugants tested were: $(a), \mathrm{Nif}^{+}$28/30; (b), $\mathrm{Nif}^{+}$30/30; (c), $\mathrm{Nif}^{+} 30 / 30 ;(d)$, $\mathrm{HiS}^{+}$2/14I ; (e), $\mathrm{Met}^{-} 49$ I 49.

\begin{tabular}{|c|c|c|c|c|c|c|c|c|}
\hline \multirow{3}{*}{$\begin{array}{l}\text { Expt } \\
\text { no. }\end{array}$} & \multirow[b]{3}{*}{ Donor } & \multicolumn{7}{|c|}{ Recipient } \\
\hline & & \multicolumn{4}{|c|}{ E. coli CI463 } & \multicolumn{3}{|c|}{ E. coli $\mathrm{K} 12 \mathrm{SBI} 80 \mathrm{I}$} \\
\hline & & $\mathrm{Km}$ & $\mathrm{Cm}$ & his & met $\mathrm{G}$ & $\mathrm{Km}$ & $\mathrm{Cm}$ & his \\
\hline I & C-M9(R I 44drd3) & $1 \times 10^{-1}$ & - & $6 \times 10^{-7}$ & $<\mathrm{I} \times 10^{-7}$ & - & - & - \\
\hline 2 & C-M9(R I44drd3)(R I $\left.d r d I_{9}\right)$ & - & $>1$ & $7 \times 10^{-4}(a)$ & $3 \times 10^{-4}$ & - & $1 \times 10^{-1}$ & $7 \times 10^{-4}(b)$ \\
\hline 3 & C-M9I(RI44drd 3$)(\mathrm{R} I d r d 19)$ & 一 & $I \times 10^{-1}$ & $<\mathrm{I} \times 10^{-7}$ & $\mathrm{I} \times 1 \mathrm{I}^{-6}$ & - & - & - \\
\hline 4 & $\mathrm{C}-\mathrm{L} 4\left(\mathrm{R} \mathrm{I}_{44} d r d_{3}\right)$ & $4 \times 10^{-1}$ & - & $5 \times 10^{-4}(e)$ & $7 \times 10^{-3}(d)$ & $2 \times 10^{-3}$ & - & $2 \times 10^{-5}(c)$ \\
\hline 5 & C-L4(R I $44 d r d 3)(\mathrm{R}$ I $d r d$ I9) & - & $3 \times 10^{-3}$ & $3 \times 10^{-4}$ & - & 一 & 一 & - \\
\hline 6 & $\mathrm{C}_{603}\left(\mathrm{R}_{144 d r d 3}\right)$ & $>\mathrm{I}$ & - & $<\mathrm{I} \times 10^{-8}$ & $1 \times 10^{-7}$ & - & - & - \\
\hline 7 & $\left.\mathrm{C} 603_{3} \mathrm{R}{ }_{4} 44 d r d 3\right)(\mathrm{R} \mathrm{I} d r d \mathrm{I9})$ & -- & $\mathrm{I} \times 1 \mathrm{O}^{-1}$ & $<\mathrm{I} \times 10^{-7}$ & $\mathrm{I} \times 1 \mathrm{I}^{-6}$ & - & - & - \\
\hline
\end{tabular}

this sex factor behaved normally in both strains and transferred chloramphenicol resistance at the high frequencies expected for a derepressed $\mathrm{R}$ factor (Table 2, Expts 2, 3 and 5). $\mathrm{R} \mathrm{I} d r d \mathrm{I} 9$ mobilized his and met $\mathrm{G}$ in C-M9 at high frequency compared with control matings with $\mathrm{C}^{6} 63$ or C-M9I, a His ${ }^{-}$segregant of C-M9, as the donor (Table 2, Expts 2, 3 and 7). The presence of RIdrdI9 had little effect on the transfer frequency observed with C-L4 (Table 2, Expt 5). The above data indicate that the his and met $\mathrm{G}$ markers which presumably originated from Klebsiella ate most probably plasmid borne in C-L4 and C-M9.

\section{Linkag, data}

Exconjugants from various crosses were purified on selective media and screened for inheritance of unselected markers. With C-M9 as donor, 58 clones out of 60 His progeny were $\mathrm{Nif}^{+-}[$Table 2 , crosses $(a),(b)]$ whereas $30 \mathrm{His}^{+}$exconjugants from a mating with C-L4 were also $\mathrm{Nif}^{+}$[Table 2, cross $(c)$ ]. This suggests that his and $n$ if were linked in both hybrids. The his and met $\mathrm{G}$ determinants were evidently not linked in C-L4: when met $\mathrm{G}$ was the selected marker, only two out of $\mathrm{I}_{4} \mathrm{I} \mathrm{Met}^{+}$exconjugants were also $\mathrm{His}^{+}$and when $h$ is was selected only 49 out of I $49 \mathrm{His}^{+}$exconjugants were Met $\mathrm{G}^{+}$[Table 2, crosses $\left.(d),(e)\right]$.

\section{Other non-selected markers inherited by hybrids}

Phage resistance. Hybrids C-M9 and C-L4 were resistant to phages $\lambda$ vir, $\lambda \mathrm{h}^{80}$, PIvir and $\phi \mathrm{X}_{\mathrm{I}} 74$. Resistance to the rough-specific phage, $\phi \mathrm{X}_{\mathrm{I}} 74$, suggested that the his-linked $r f b$ genes of Klebsiella were transferied to both hybrids (Cannon et al. 1974). Cannon et al. (1974) described the isolation and some characteristics of the hybrid-specific phage, ECI. Although hybrids C-M9 and C-L4 were sensitive to the phage, resistant variants arose at a high frequency. All of I63 ECI-resistant clones of C-M9 tested were $\mathrm{His}^{-}$and $\mathrm{Nif}^{-}$.

Colony form. In contrast to a stable $\mathrm{Nif}^{+}$hybrid, C-M7, both C-M9 and C-L4 produced mucoid colonies which suggests that they inherited genes affecting the production of extracellular polysaccharides. Since his was the selective marker for these hybrids, a locus in the Klebsiella donor equivalent to the his-linked non (non-mucoid) locus of Escherichia coli KI2 (Radke \& Siegel, 197I) could affect capsule synthesis in E. coli C.

Gluconate-6-phosphate dehydrogenase. Strain C-M7, with chromosomally integrated Klebsiella DNA, contained only one electrophoretically distinguishable form of this dimeric 


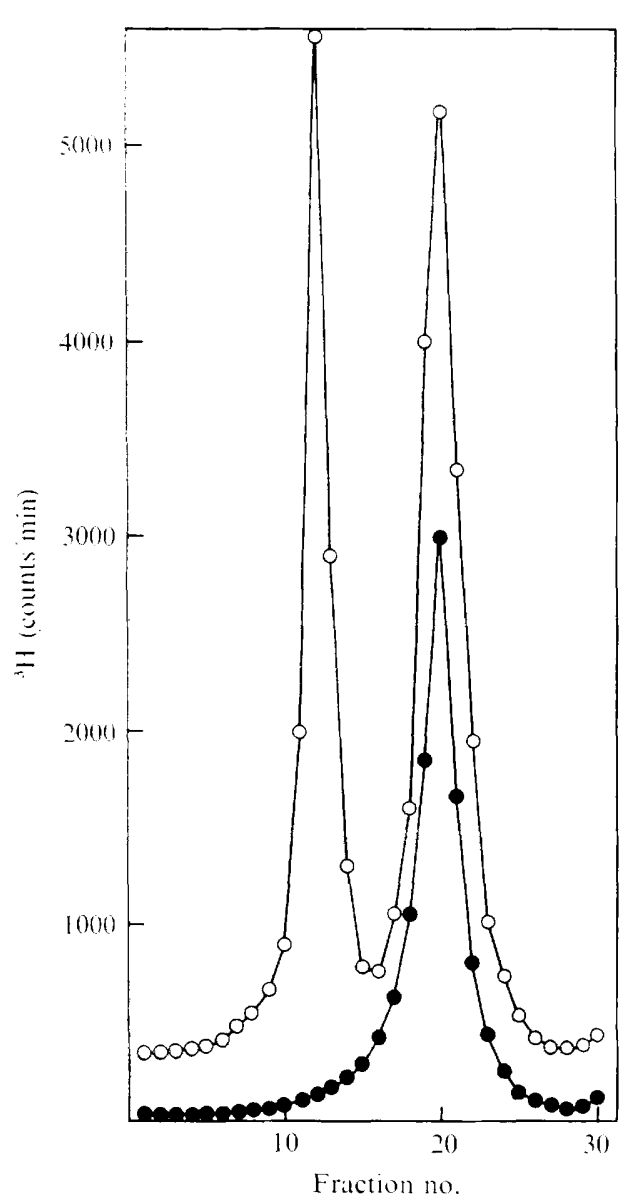

Fig. I

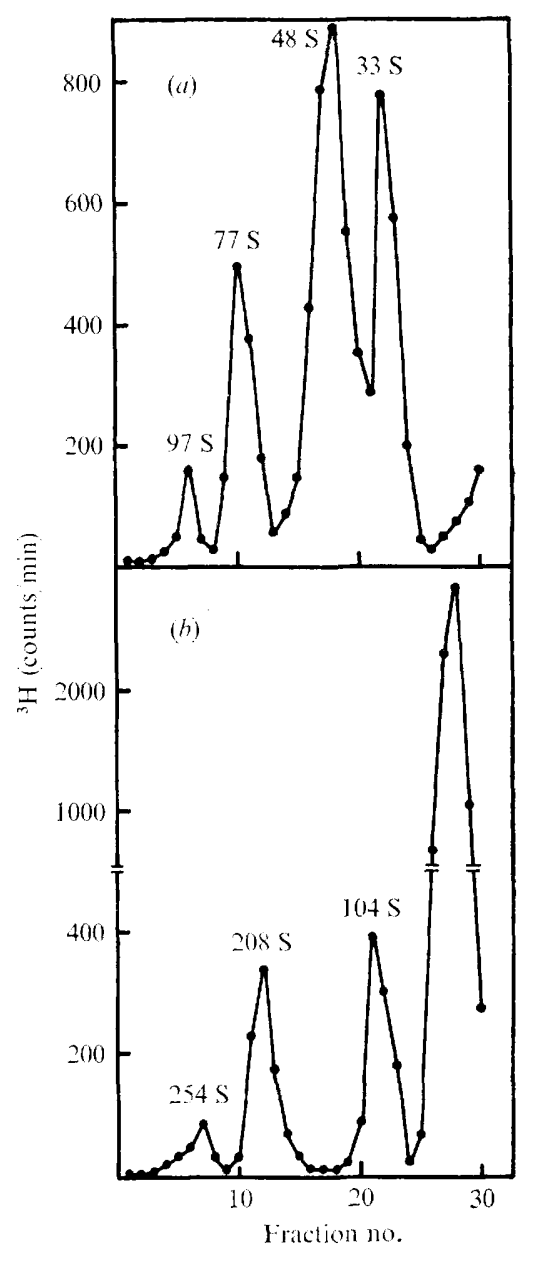

Fig. 2

Fig. 1. Fractionation of DNA in cleared lysates of Escherichia coli $\mathrm{C} 603(0)$ and hybrid C-M9 $(O)$, grown in $20 \mathrm{ml}$ cultures, after dye-buoyant density centrifugation at $126000 \mathrm{~g}$, 0 to $2{ }^{\circ} \mathrm{C}$ for $16 \mathrm{~h}$. Clear lysates were prepared by a lysozyme-EDTA-Triton X-IOo procedure (Cannon et al. I974). After centrifugation, fractions (Io drops) were collected in styrene 'Microtiter' plates. A portion $(0.0 \mathrm{I} \mathrm{ml})$ of each fraction was spotted on a filter disc and assayed for ${ }^{3} \mathrm{H}$ radioactivity.

Fig. 2. Profiles of DNA from hybrid C-M9, analysed by velocity centrifugation in neutral $(a)$ and alkaline (b) $5 \mathrm{ml}, 5$ to $20 \%$ sucrose gradients. Fractions of the denser band from dye-buoyant density gradients were pooled and dialysed against TES-2 buffer. Portions (100 $\mu \mathrm{l})$ of the pooled fractions, mixed with $100 \mu \mathrm{l} \mathrm{Col} \mathrm{EI} \mathrm{DNA} \mathrm{solution} \mathrm{were} \mathrm{layered} \mathrm{on} \mathrm{gradients} \mathrm{and} \mathrm{centrifuged} \mathrm{for} 45 \mathrm{~min}$ (a) and $20 \mathrm{~min}(\mathrm{~b})$ at $\mathbf{I} 20000 \mathrm{~g}$ in a 52 rotor at $20{ }^{\circ} \mathrm{C}$ using a Christ $\omega$ II ultracentrifuge. After centrifugation, seven-drop fractions were collected directly on to Whatman no. 3 filter discs and cold TCA precipitable label assayed for ${ }^{3} \mathrm{H}$ radioactivity.

enzyme, though the parent Klebsiella and Escherichia enzymes are distinguishable (Cannon et al. 1974). Polyacrylamide gel electrophoresis indicated three species of the enzyme in C-M9. The $R_{F}$ values of two of these species corresponded to those of the enzyme from the parent Klebsiella $(0.38)$ and Escherichia $(0.47)$ strains. The third species had an intermediate $R_{k}$ value $(0 \cdot 43)$ and was presumably a hybrid of one Klebsiella and one Escherichia coli 
Table 3. Molecular weights of circular DNA molecules from hybrid C-M9

Molecular weight were calculated from $s_{20, w}$ values using the data of Bazaral \& Helinski (1968).

\begin{tabular}{ccc}
\multicolumn{2}{c}{$s_{20, \mathrm{w}}$ of CCC molecules } & $\begin{array}{c}\text { Molecular weight } \\
\text { (daltons) }\end{array}$ \\
Neutral sucrose & Alkaline sucrose & $69 \times 10^{6}$ \\
77 & 208 & $1 \mathrm{I} 8 \times 10^{6}$ \\
97 & 254 & $9.5 \times 10^{6}$
\end{tabular}

monomeric subunit. This form was not observed when the parental enzymes were mixed in vitro. These results imply that C-M9 carried both parental gnd alleles.

\section{Isolation and characterization of supercoiled DNA from hybrids}

Cultures of Eschichia coli $\mathrm{C} 603$, hybrids C-M9 and C-L4, were labelled with tritiated thymidine and gently lysed by the lysozyme-Triton X-100 procedure to obtain cleared lysates (Cannon et al. 1974). These were then centrifuged in ca esium chloride with ethidium bromide. DNA from both hybrids was resolved into two bands on the density gradients; the denser band was characteristic of CCC-DNA while the less dense band contained open circular (OC) and linear DNA (Fig. 1). CCC-DNA was not obtained from strain 6603 under the experimental conditions used. Pooled fractions of the denser bands were dialysed against TES-2 buffer and analysed by velocity centrifugation as described by Cannon et al. (1974).

Hybrid C-M9. The combined results from neutral and alkaline sucrose gradients showed that C-M9 contained three species of CCC-DNA (Fig. $2 a, b$ ). One of the CCC-DNA species was RI44drd3: it had S values of 77 for the CCC and 48 for the OC forms, the values established for this plasmid (Cannon et al. I974). The remaining CCC-DNA species apparently arose from Klebsiella chromosomal DNA transferred to C-M9, since CCC-DNA was not observed in Klebsiella pneumoniae M5a I and R I 44drd 3 was the only plasmid observed in its derivative donor strain, HF3 (unpublished). The $S$ values of the plasmids formed in C-M9 were calculated from the $\mathrm{S}$ value of either Col EI or RI44drd3 CCC-DNA; assuming a linear relationship between the $\mathrm{S}$ value and the distance sedimented, they were $97 \mathrm{~S}$ and $254 \mathrm{~S}$ for the CCC-form of the larger plasmid in neutral and alkaline gradients respectively, and $33 \mathrm{~S}$ and ${ }_{104} \mathrm{~S}$ for that of the smaller plasmid. The molecular weights of these plasmids, calculated from the $\mathrm{S}$ values of their $\mathrm{CCC}$-forms in neutral sucrose gradients using the data of Bazaral \& Helinski (I968), were I I $8 \times 10^{6}$ and $9.5 \times 10^{6}$ daltons (Table 3 ).

The supercoiled DNA of an ECI-resistant segregant (C-M9I) of C-M9, which was His ${ }^{-} \mathrm{Nif}^{-}$, was examined in sucrose gradients (Fig. $3 a, b$ ). The CCC-DNA species from C-M9 of $33 \mathrm{~S}$ in neutral and ${ }_{104} \mathrm{~S}$ in alkaline sucrose gradients was absent, though otherwise the profiles for C-M9 and C-M9I were identical. Hence C-M9I retained RI44drd 3 and a larger plasmid which presumably orginated from a segment of the Klebsiella chromosome. Therefore his and nif were probably located on a plasmid of molecular weight $9.5 \times 10^{6}$ daltons in C-M9.

Hybrid C-L4. Comparable combined results showed that C-L4 contained four species of CCC-DNA (Fig. 4a,b). The most rapidly sedimenting CCC-DNA species in neutral sucrose gradients had an $S$ value of 92 . In alkaline conditions this plasmid was centrifuged to the bottom of the gradient. A CCC species of $71 \mathrm{~S}$ in neutral sucrose and $208 \mathrm{~S}$ in alkaline sucrose was most probably RI44drd3. Two additional rapidly sedimenting components characteristic of CCC-DNA were resolved in alkaline sucrose gradients. These plasmids (I73 S and II2 S) partially overlapped with the $77 \mathrm{~S}$ and $48 \mathrm{~S}$ forms, respectively, of R I44$d r d_{3}$ in neutral sucrose gradients. 


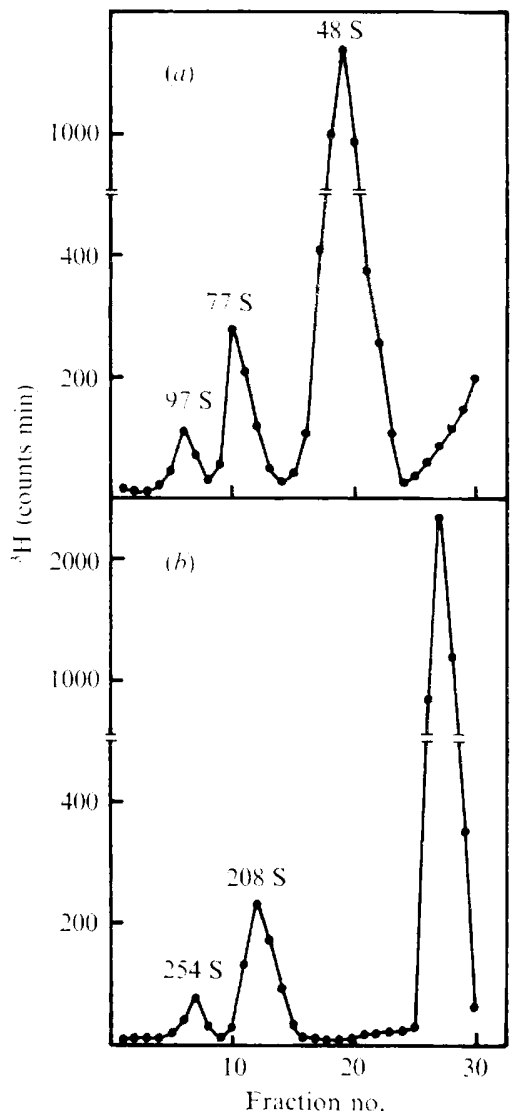

Fig. 3

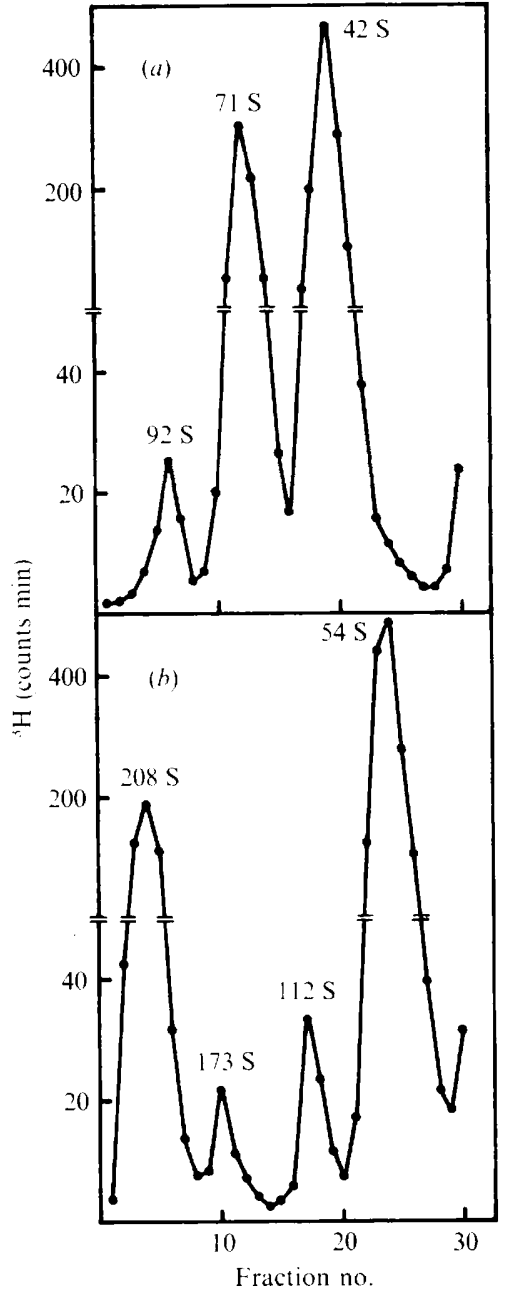

Fig. 4

Fig. 3. Characterization of supercoiled DNA from an Escherichia coli Nif- segregant, C-M9I, by velocity centrifugation in $5 \mathrm{ml}$ neutral $(a)$ and alkaline $(b) 5$ to $20 \%$ sucrose gradients. Supercoiled DNA, purified by dye-buoyant density centrifugation, was dialysed against TES-2 buffer and portions ( $100 \mu \mathrm{l}$ of C-M9I DNA and $100 \mu 1$ of Col EI DNA) layered on sucrose gradients. Centrifugation was carried out for $45 \mathrm{~min}(a)$ and $20 \mathrm{~min}(b)$ at $\mathrm{I} 20000 \mathrm{~g}$ in a 52 rotor at $20^{\circ} \mathrm{C}$ using a Christ $\omega$ II ultracentrifuge. Gradients were fractionated by drop collection ( 7 drops/fraction) directly on to Whatman no. 3 filter discs and cold TCA precipitable label assayed for ${ }^{3} \mathrm{H}$ radioactivity.

Fig. 4. Profiles of DNA from hybrid C-L4, analysed by velocity centrifugation in neutral $(a)$ and alkaline $(b) 5 \mathrm{ml}, 5$ to $20 \%$ sucrose gradients. Supercoiled DNA, obtained from dye-buoyant density gradients, was dialysed against TES-2 buffer and portions (100 $\mu$ l of C-L4 DNA and $100 \mu$ l of Col EI DNA) layered on sucrose gradients. Centrifugation was carried out for $45 \mathrm{~min}(a)$ and $30 \mathrm{~min}(b)$ at $120000 \mathrm{~g}$ in a 52 rotor at $20^{\circ} \mathrm{C}$ using a Christ $\omega I I$ ultracentrifuge. Gradients were fractionated by drop collection ( 7 drops/fraction) directly on to filter discs and TCA precipitable label assayed for ${ }^{3} \mathrm{H}$ radioactivity. 


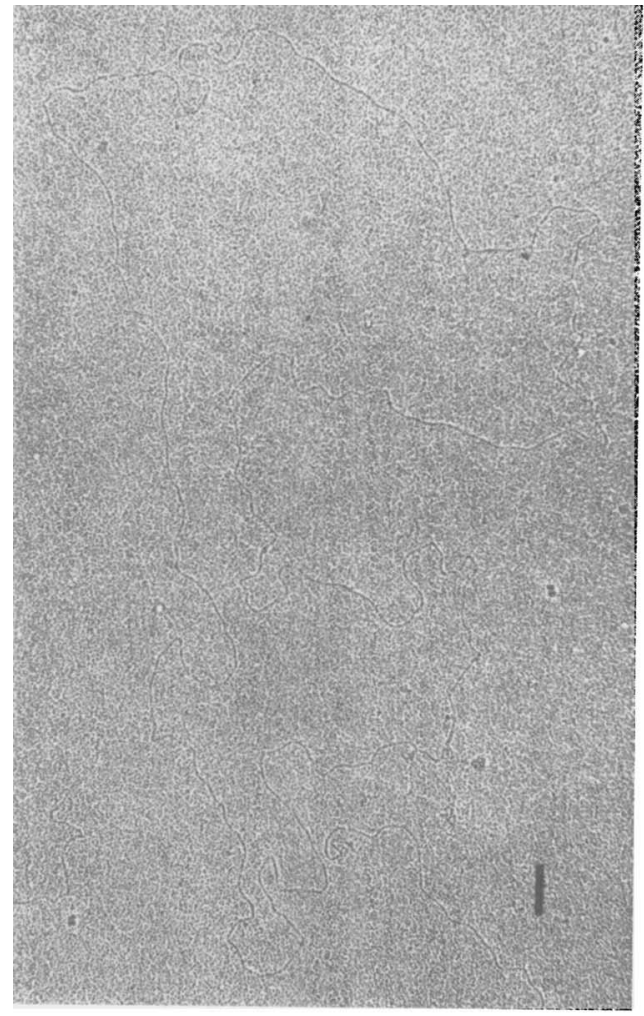

(a)

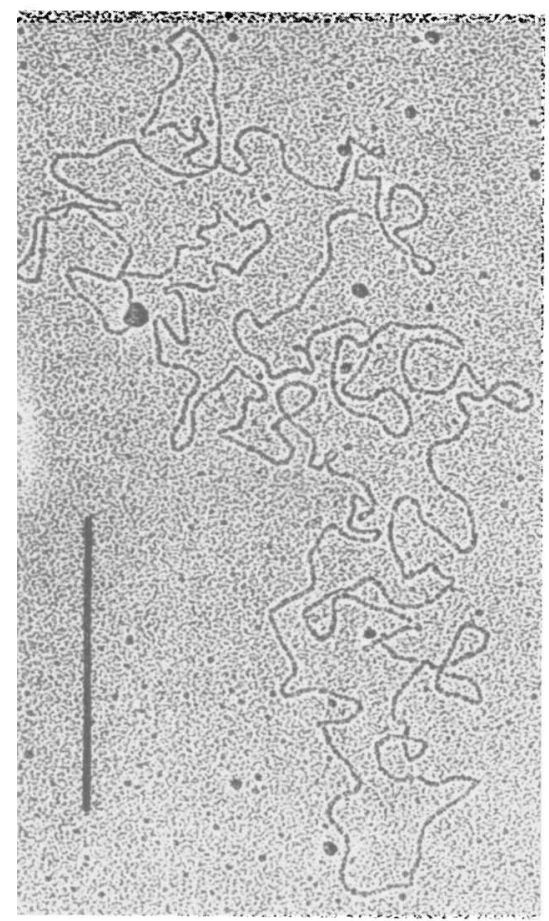

(c)

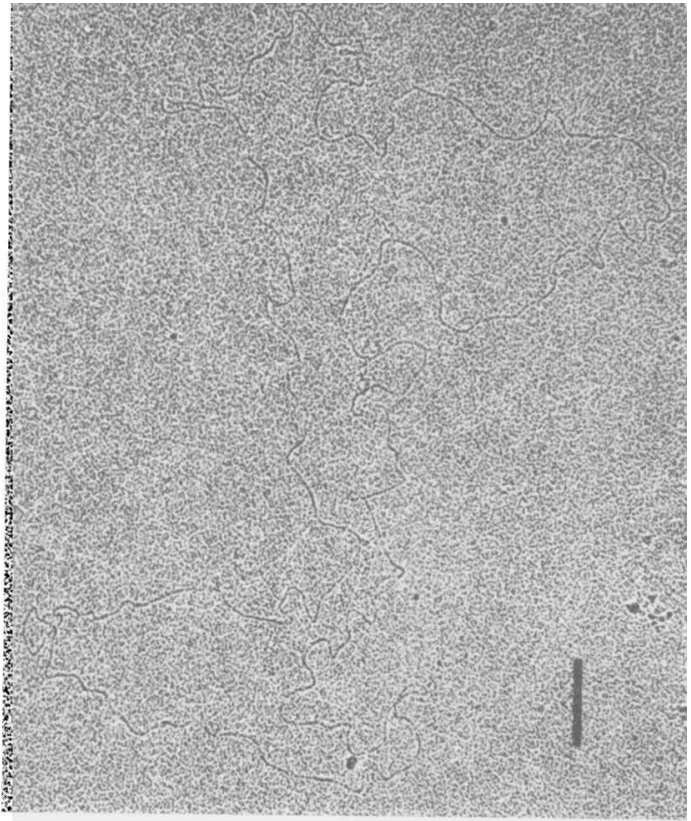

(b)

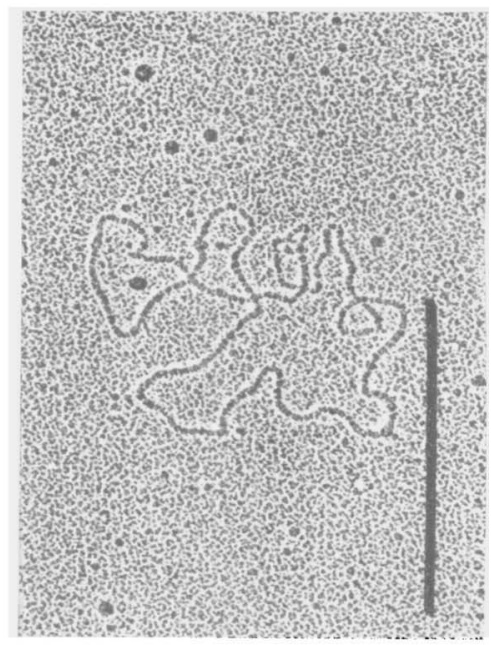

(d)

Fig. 5. Electron micrographs of circular DNA from hybrid C-L4, purified by dye-buoyant density centrifugation, showing members of four classes with mean Col EI DNA equivalents of $(a) 24 \cdot 8$, (b) $14 \cdot 5,(c)$ I I and $(d) 2 \cdot 8$. Bars represent I $\mu \mathrm{m}$. 
Table 4. Molecular weights of circular DNA molecules from hybrid C-L4

\begin{tabular}{|c|c|c|c|c|c|}
\hline \multicolumn{6}{|c|}{$s_{20, w}$ of CCC molecules } \\
\hline $\begin{array}{l}\text { Neutral } \\
\text { sucrose }\end{array}$ & $\begin{array}{l}\text { Alkaline } \\
\text { sucrose }\end{array}$ & $\begin{array}{l}\text { Molecular } \\
\text { weight* } \\
\text { (daltons) }\end{array}$ & $\begin{array}{l}\text { No. of } \\
\text { molecules } \\
\text { measured }\end{array}$ & $\begin{array}{c}\text { No. of EI DNA } \\
\text { equivalents }\end{array}$ & $\begin{array}{l}\text { Molecular } \\
\text { weight } \dagger \\
\text { (daltons) }\end{array}$ \\
\hline 一 & 208 & $69 \times 10^{6}$ & 20 & $14.5 \pm 0.25$ & $61 \times 10^{6}$ \\
\hline 92 & - & $106 \times 10^{6}$ & 6 & $24 \cdot 8 \pm 0.3$ & $104 \times 10^{6}$ \\
\hline - & 173 & - & 8 & $I I \pm 0.2 I$ & $46 \times 10^{6}$ \\
\hline - & 112 & - & 28 & $2.8 \pm 0 . I$ & $12 \times 10^{6}$ \\
\hline
\end{tabular}

* Calculated from $s_{20, \mathrm{w}}$ values using the data of Bazaral \& Helinski (I968).

$\uparrow$ Calculated from contour lengths assuming a molecular weight of $4.2 \times 10^{6}$ daltons for Col EI DNA.

\section{Electron microscopy}

Electron micrographs of plasmids from hybrid C-L4 are shown in Fig. 5 and measurements of contour lengths are presented in Table 4. Four distinct sizes were observed among the molecules examined, corresponding to the four sedimentation types. The molecular weights calculated from the contour lengths (see Methods) agreed well with those derived from sedimentation coefficients.

\section{DISCUSSION}

In contrast to hybrid C-M7, where a fragment of Klebsiella DNA is probably integrated into the Escherichia coli chromosome (Cannon et al. 1974), the two hybrids studied here harboured multiple plasmids which were apparently derived from the Klebsiella chromosome (see below). The presence of three plasmids in hybrid C-M9 and four in C-L4 made their assignment difficult. Unfortunately, we were unable to purify sufficient DNA of each plasmid for use in transformation experiments, and since the hybrids were resistant to transducing phage we were also unable to study the plasmids by transduction. Therefore, although it was possible to characterize these plasmids physically using sucrose density gradients and electron microscopy, it was not feasible to assign a function to each $\mathrm{CCC}$ molecule unequivocally.

Both hybrids carried a plasmid identifiable as R I $44 d r d_{3}$, the R factor originally introduced into the donor strain of Klebsiella pneumoniae (Dixon \& Postgate, 1971). Strain C-M9 contained a plasmid of molecular weight $9.5 \times 10^{6}$ daltons whose loss in C-M9I was accompanied by loss of nif and other his-linked characters; this plasmid presumably carried nif and associated determinants. The presence of three classes of gluconate-6-phosphate dehydrogenase in hybrid C-M9 is unequivocal evidence for duplication of the gnd locus in this hybrid; presumably the Klebsiella gnd determinant is also carried on this plasmid because gnd maps close to nif (Cannon et al. 1974).

The corresponding plasmid in C-L4 was not identified in this way; it may be the one of molecular weight $\mathrm{I} 2 \times 10^{6}$ daltons. The ready mobilization of his and nif by $\mathrm{R} 144 d r d 3$ in this strain provides evidence that these determinants are plasmid-borne and contrasts with the situation in C-M9 in which R $144 d r d 3$ did not mobilize efficiently. The met $\mathrm{G}$ determinant in hybrid C-L4, which presumably originated from Klebsiella, was transferred at high frequency by R I44drd 3 and was not linked to his. The Klebsiella met $\mathrm{G}$ determinant may therefore be carried on another of the three plasmids identified in this hybrid.

A consequence of the formation of nif-bearing plasmids in these hybrids is that gene transfer is no longer hindered by problems arising from differences in nucleotide sequence 
homology and host-specific restriction. Hence numerous $\mathrm{Nif}^{+}$strains of Escherichia coli K I 2 were obtained (Table 2), which could not reasonably have been expected from a direct mating with Klebsiella pneumoniae unless a mutant deficient in host-specific restriction were chosen. The primary genetic barrier to more widespread transfer of the nif operon is now the host range of existing sex factors and their ability to mobilize the nif-bearing plasmid. In many organisms, however, the reduced conditions required for expression of nif (see Postgate, 197I) may present a phenotypic obstacle to obtaining nitrogen-fixing strains in practice.

The presence of multiple plasmids derived from Klebsiella chromosomal DNA in the two hybrids contrasts with the situation in the Escherichia-Salmonella hybrids studied by Leavitt et al. (197I). Each Salmonella hybrid contained only one plasmid, though among the hybrids a wider range of plasmid molecular sizes occurred; the upper range of size of the Salmonella plasmids was considerably larger than that in our Escherichia coli hybrids. The origin of the plasmids in $E$. coli is a complex question. They did not exist as free plasmids in the original donor strain of Klebsiella (Klebsiella pneumoniae strain HF3: Dixon \& Postgate, I972) because no plasmid other than RI $44 d r d 3$ could be detected in this strain; nor could a plasmid be detected in the recipient strain E. coli c603. Presumably large segments of Klebsiella DNA were transferred, but whether these fragmented before forming several CC circles or whether a large circle was formed which looped off smaller circles is not known. Since each plasmid presumably originated from a segment of the Klebsiella chromosome it is difficult to visualize how each DNA molecule is able to replicate autonomously, and the establishment of new replicons in each hybrid is an extremely vexing problem. The DNA segments may have gained the ability to replicate by recombination with cryptic replicons which cannot be detected by our physico-chemical procedures. Alternatively, the Klebsiella chromosome itself may contain redundant replicons which became expressed after transfer to E. coli.

We thank Miss Anne Bates and Miss Vicki Smith for invaluable technical assistance.

\section{REFERENCES}

Baron, L. S., Gemski, P., Jun., Johnson, E. M. \& Wohlhieter, J. A. (1968). Intergeneric bacterial matings. Bacteriological Review's 32, 362-369.

BazAral, M. \& Helinski, D. R. (1968). Characterization of multiple circular DNA forms of colicinogenic factor EI from Proteus mirabilis. Biochemistry 7, 35 I 3-35I9.

Cannon, F. C., Dixon, R. A., Postgate, J. R. \& Primrose, S. B. (i974). Chromosomal integration of Klebsiella nitrogen fixation genes in Escherichia coli. Journal of General Microbiology 8o, 227-239.

Davis, R. W., Simon, M. \& Davidson, N. (197I). Electron microscope heteroduplex methods for mapping regions of base sequency homology in nucleic acids. In Methods in Enzymology, vol. 21, pp. 4I3-428. Edited by L. Grossman and K. Moldave. New York and London: Academic Press.

Dixon, R. A. \& Postgate, J. R. (1971). Transfer of nitrogen fixation genes by conjugation in Klebsiella pneumoniae. Nature, London 234, 47-48.

Dixon, R. A. \& Postgate, J. R. (1972). Genetic transfer of nitrogen fixation from Klebsiella pneumoniae to Escherichia coli. Nature, London 237, $102-103$.

Falkow, S., Schneider, H., Baron, L. S. \& Formal, S. B. (1963). Virulence of Escherichia-Shigella genetic hybrids for the guinea pig. Journal of Bacteriology 86, $125 \mathrm{I}-1258$.

Gemski, P., Jun., Wohlheiter, J. A. \& BARon, L. S. (1967). Chromosome transfer between Escherichia coli Hfr strains and Proteus mirabilis. Proceedings of the National Academy of Sciences of the United States of America 58, 146I-I467.

Leavitt, R. W., Wohlieter, J. A., Johnson, E. M., Alson, G. E. \& Baron, L. S. (197I). Isolation of circular deoxyribonucleic acid from Salmonella typhosa hybrids obtained from matings with Escherichia coli $\mathrm{Hfr}$ donors. Journal of Bacteriology 108, I357-1365. 
MojicA-A, T. \& Middleton, R. B. (1972). Salmonella typhimurium-Escherichia coli hybrids for the tryptophan region. Genetics 7I, 49I-505.

Postgate, J. R. (197I). Fixation by free-living microbes: physiology. In The Chemistry and Biochemistry of Nitrogen Fixation, pp. I6I-190. Edited by J. R. Postgate. London: Plenum Press.

RADKE, K. L. \& SiegEL, E. C. (I97I). Mutation preventing capsular polysaccharide synthesis in Escherichia coli $\mathrm{K} I 2$ and its effects on bacteriophage resistance. Journal of Bacteriology ro6, 432-437.

Streicher, S. L., Gurney, E. G. \& Valentine, R. C. (197I). Transduction of the nitrogen fixation genes in Klebsiella pneumonia. Proceedings of the National Academy of Sciences of the United States of America 68, I I 74-I I 77 .

TAYlor, A. K. \& Trotter, C. D. (1972). Linkage map of Escherichia coli strain KI 2. Bacteriological Reviews 36, 504-524. 